\title{
Global analysis of the infection by COVID-19
}

\author{
Marcos Silveira Buckeridge
}

I Program USP-Global Cities, Institute of Advanced Studies, Department of Botany, Institute of Biosciences, University of São Paulo (USP)

São Paulo/SP - Brasil

\begin{abstract}
The evolution of the pandemic of COVID-19 globally has generated one of the most significant historical events of the 21st Century, with unpredictable consequences to the economy, environment, and world health. Here I compiled data available in databases to examine the levels of infections of 56 countries displaying over 5,000 confirmed cases and calculated the percentage of infection by 100,000 inhabitants. The pattern found revealed a striking difference between Asian and European countries, with much higher infection levels in the later. Countries from Latin America and the Middle East were intermediate. Three factors might have generated the observed pattern: social distancing strategy, genetic factors, and testing level. I conclude that pandemic evolution would be better explained as a multifactorial phenomenon that would be better viewed systemically.
\end{abstract}

Keywords: COVID-19, infection, global analysis, social distancing, testing.

São Paulo. Vol. 23, 2020

Debating ideas

The COVID-19 epoch: Interdisciplinary research towards a new just and sustainable ethics

DOI: http://dx.doi.org/10.1590/1809-4422asoc20200121vu2020L3ID 
Surge and spread of COVID-19. The virus SARS-Cov-2 devastated the world through a pandemic that initiated in China in December 2019. The disease was named COVID-19 (COronaVIrus Disease of 2019). It spread quickly from the Wunan region, in China, to the rest of Asia, to the European and Middle East countries, and North America. Subsequently, the virus also started spreading through South America and Africa. By the 24th of May, when this article is being written, the number of cases confirmed globally has been reported by the Johns Hopkins University as of 5,334,675, and the number of global deaths is of 341,513 . The number of globally reported daily cases has reached a plateau since around the 10th of April with no sign of decrease.

The pandemic is now considered a severe threat to world health and the socioeconomic status of the whole world. The world economy is expected to enter a recession period comparable to the Crash of 1929.

The coronaviruses origin and infection mechanism. The SARS-Cov-2 is a type of Coronavius that belongs to the order Nidovirales, family Coronavirideae. They are enveloped RNA-containing viruses found in birds and mammals (HULSWIT et al., 2019). Some of the coronaviruses have successfully adapted to infect human cells and cause severe pulmonary diseases (VIJGEN et al., 2006).

The transmission of the SARS-Cov-2 occurs mainly through aerosols exhaled by infected individuals. The virus can survive in the environment, and particles are found in the environment, potentially transmitting also in this way (LIU et al., 2020). As it enters the human body, it has to invade cells to replicate itself. The coronaviruses display RNA instead of DNA (HULSWIT et al., 2019). This genetic material is included in a protein capsid. The SARS-Cov-2 is further enveloped by a lipid membrane. The shape of the coronavirus particles is long known as being spherical and displaying spikes. The spikes contain a glycoprotein named S-protein. As reviewed by Sanders et al. (2020), when the virus enters in contact with the surface of the human cell, the S-protein interacts with membrane receptors of human cells (ACE2 receptor, TMPRSS2, and IL-6 receptor). If the recognition pattern matches correctly, the virus particle will enter the human cell by forming membrane vesicles named caveolae. Wrapped by our membrane vesicles, the virus gains the cytoplasm and starts to use the protein synthesis machinery to replicate itself.

Figure 1 shows Vero cells (lineage of cells of the monkey Chlorocebus sp. used as a model to test virus infections) with the SARS-Cov-2 virus. The cells are colored in blue and the virus in green.

The infection is clearly seen through the presence of numerous virus particles within the cytoplasm of the cells (green). 
Figure 1. Vero cells subjected to infection with the coronavirus SARS-Cov-2 that provokes COVID-19 in humans

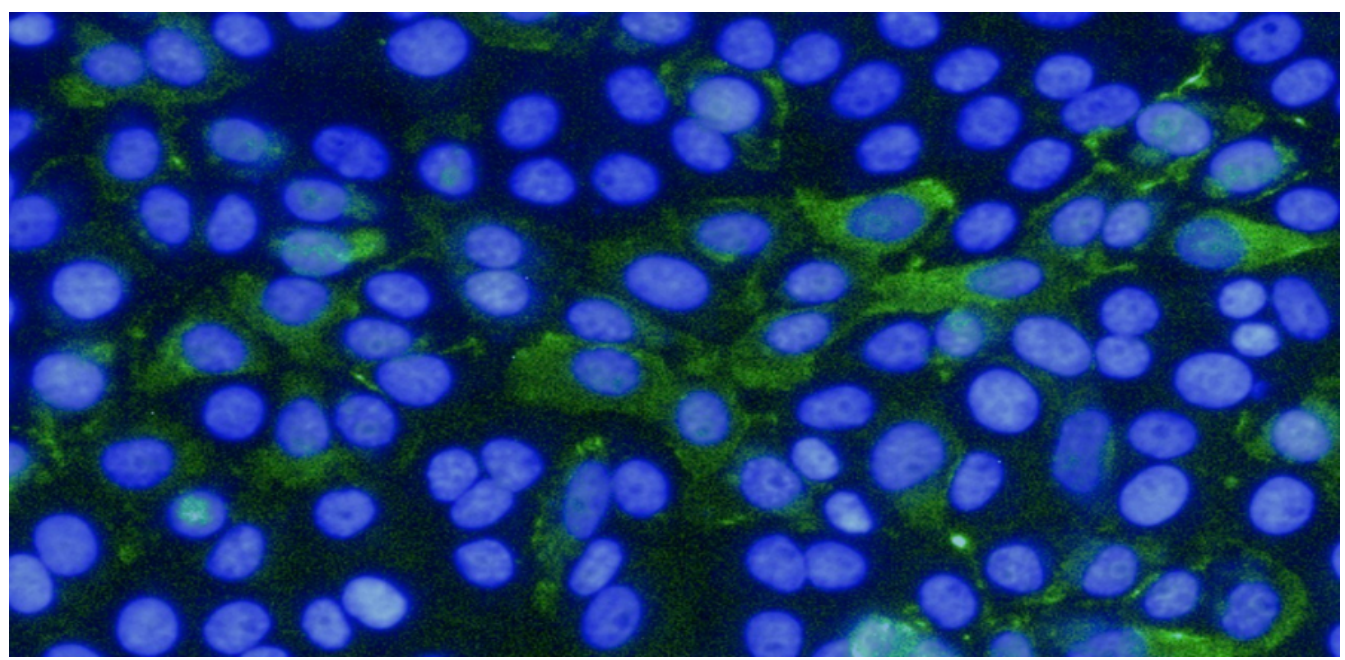

The image is produced by fluorescence microscopy using DAP, which stains the cell nuclei and is colored in blue. The SARS-Cov-2 particles (green) were stained using antibodies from the serum of an infected COVID-19 patient. Source: picture from ongoing experiment in collaboration with the Phenotypic Screening Platform, Institute of Biomedical Sciences, University of São Paulo).

An encoding mechanism involves recognizing signs of the virus capsid, and the cell's receptors - similar to the human receptors - are necessary for the virus to enter human or monkey cells. Thus, it is plausible to hypothesize that the genetic variability of the virus and the human population might influence the infection levels in different ways.

Global analysis of COVID-19 cases: To test this hypothesis for human populations, I compiled data of reported cases of COVID-19 for 56 countries of several continents, as reported by the website of the Johns Hopkins University. I also compiled the population size for each country on the list and calculated the number of infected inhabitants per 100,000 . I used data reported by the website for the 10th and the 21st of May and chose the list of countries that had more than 5,000 cases reported on the 10th of May. On these dates, several countries were at the peak of daily infections or had passed this peak. Some were still increasing the daily infection. Figure 2 shows the percentage of increase in daily cases during the 11 days. I grouped countries in the following way: Asia, Africa, Latin America, Middle East, Western Europe, Europe, and North America.

At the time I collected the data, neither correlations were found between the percentages of cases with the size of the population nor with their population density.

The "global" average increase over the 11 days studied was $20.5 \%$, with 33 (ca. $60 \%$ ) countries below the average and 23 (ca.40\%) above it (Figure 2). Countries above the average display up to $56.6 \%$ of increase over the 11 days. Most of these countries are from Asia, Latin America, and the Middle East. Alternatively, among the countries below 
the average, the European and some Asian countries are the most abundant.

Figure 2. Percentagem increase in the number of cases of COVID-19 from 10 to 21 of May 2020

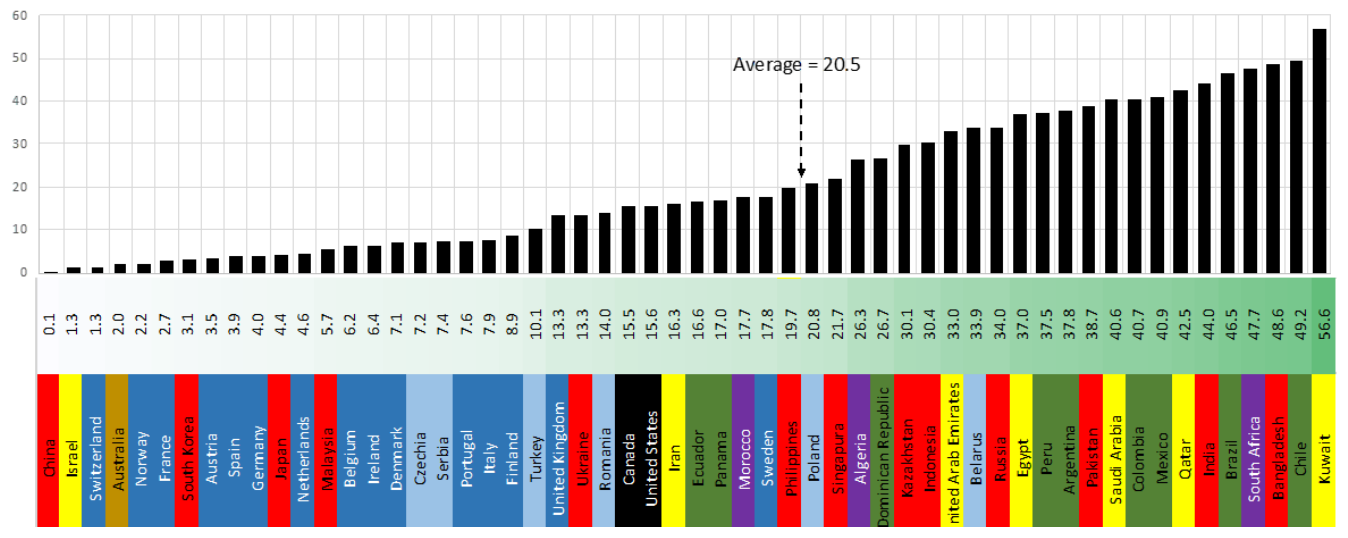

Sources: case numbers were obtained from the website of the Johns Hopkins University (https://coronavirus.jhu.edu/map.html). Population data were obtained from internet data for populations reported for 2018 and 2019 using data available in the internet.

The examination of the distribution of the number of cases through the 56 countries on the 10th and the $21^{\text {st }}$ of May revealed that several countries appear to group according to the region in the world (Figure 3). In fact, the distribution of cases displayed a remarkably low number (below 50) of cases per 100,000 inhabitants. Alternatively, above the average (201 cases), the number of confirmed cases increases linearly, forming a plateau above 470 cases and having Qatar case number off the scale. One clear feature of the distribution of countries within the very low cases (below 50) and the above average (201) cases is a quite clear separation between Asia and Europe. 
Figure 3. The number of reported cases of COVID-19 in 56 countries classified according to the number of cases per 100,000 inhabitants

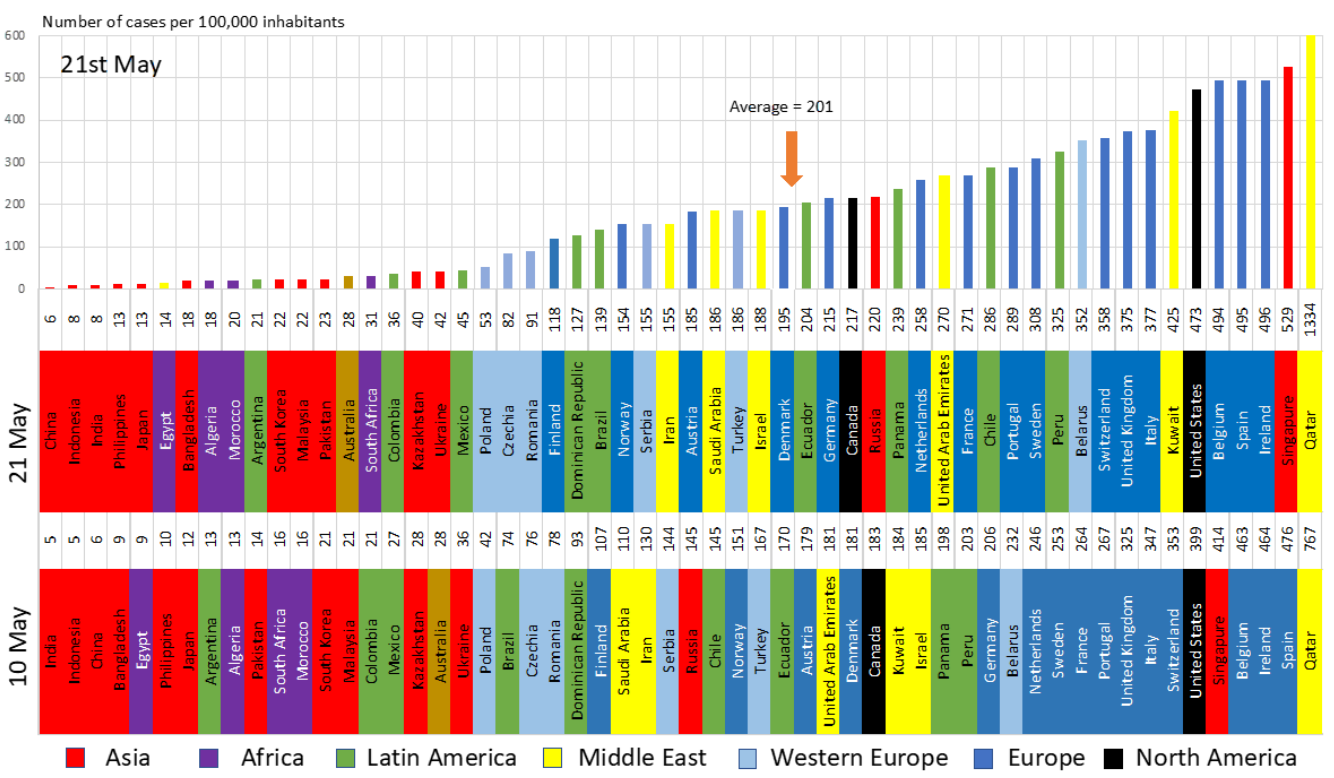

Sources: case numbers were obtained from the website of the Johns Hopkins University (https:/coronavirus.jhu.edu/map.html). Population data were obtained from internet data for populations reported for 2018 and 2019 using data available in the internet.

Countries like China, Japan, and South Korea - which displayed high testing capacity - have already decreased the number of daily cases significantly in the same way that several European and North American countries (the US and Canada) - also with relatively high testing capacity - reached much higher levels of infection (e.g., Belgium, Ireland, France, Germany, Spain, and Portugal). Even so, such countries show a persistent (4 to10-fold) difference when Asia and Europe/North America are compared. Latin American and Middle East countries show intermediate distributions, whereas African countries display relatively lower cases. These countries are among the latest countries to be infected by SARS-Cov-2 - and were still increasing the case numbers (Figure 3) and the distribution in the range of confirmed case numbers is probably going to change over the next few weeks.

Possible explanations. According to the percentage of confirmed cases, the countries' distribution might be explained by three possible hypotheses that are mutually exclusive. The first refers to the strategy used by different countries is social distancing (lockdown, forced social separation). Modeling made by Kissler et al. (2020) suggested that a one-time intervention of social distancing would be insufficient to keep control of the spread of COVID-19 in the US. Even so, countries that used such a strategy might have reduced the infection level and partly explain the grouping found on the 10th of May for the 56 countries examined here (Figure 4). 
Figure 4. Correlation between the number of confirmed cases for 49 countries (out of the 56 in Figures 2 and 3) and the total tests per million of inhabitants

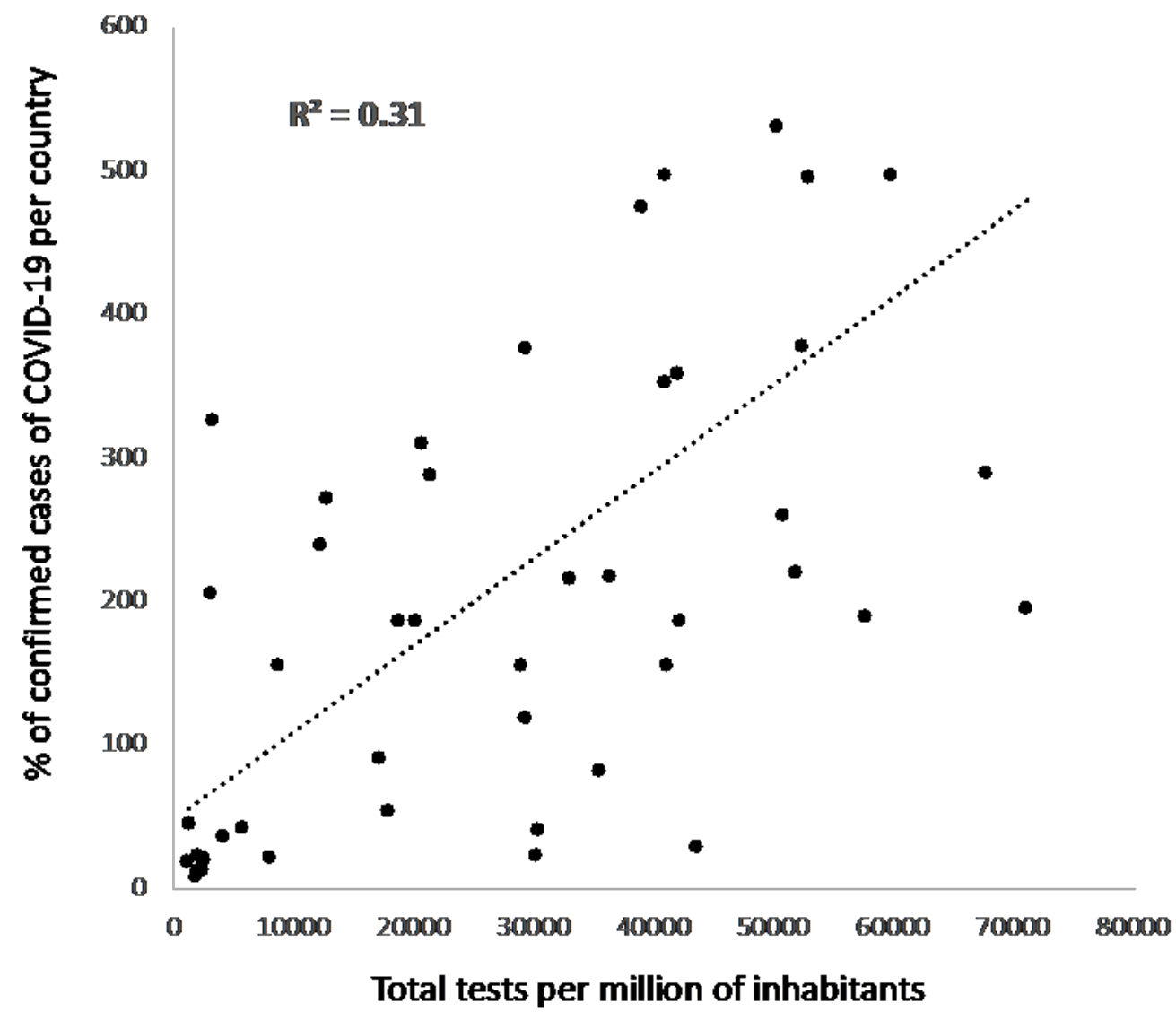

Souce: compiled by the author from https://ourworldindata.org/coronavirus-testing.

A second possible strategy that might have interfered to some extent on COVID-19 spreading globally could be related to genetic factors. In this case, one may hypothesize that mutations (e.g. of the receptors mentioned above) depending on different populations around the world, could facilitate or prevent the virus's entry into the cells. This remains to be investigated further by using bioinformatic tools using the genomic and transcriptomic data available in gene databases. However, the finding that black Britons display twice as many deaths than other ethnicities seems to confirm this hypothesis. ${ }^{1}$ The third possibility is that the testing level might have influenced the number of confirmed cases. To test this hypothesis, I compiled data from the Our World in Data (https://ourworldindata.org/coronavirus-testing) and correlated the available data on total testing reported with the percentage of confirmed cases (Figure 4). Some correlation seems to

1 - Coronavirus: Black Britons face 'twice the risk' of death, says ONS. BBC - https://www.bbc.com/news/uk-52574931, acesso em $7 / 6 / 2020$. 
exist $(\mathrm{r} 2=0.31)$, but data is quite dispersed, strongly suggesting that the data is influenced by more than one variable.

My observations suggest that the pandemic evolution may be a multifactorial phenomenon, suggesting that systemic tools would be adequate to understand the events and to make decisions.

\section{References}

HULSWIT, R.J.G.; LANG, Y.; BAKKERS, M.J.G. et al. Human coronaviruses OC43 and HKU1 bind to 9-O-acetylated sialic acids via a conserved receptor-binding site in spike protein domain A. Proceedings of the National Academy of Sciences. v.,116: p. 2681-2690. 2018.

KISSLER, S.; TEDIJANTO, C.; LIPSITHCH, M. et al. Social distancing strategies for curbing the COVID-19 epidemic. Harvard University DASH repository. http://nrs.harvard.edu/urn-3:HUL.InstRepos:42638988. 2020.

LIU, Y.; NING, Z.; CHEN, Y. et al. Aerodynamic analysis of SARS-CoV-2 into two Wunan hospitals. Nature. https://doi.org/10.1038/s41586-020-2271-3. 2020.

SANDERS, J.M.; MONOGUE, M.L.; JODLOWSKI, T.Z. et al. Pharmacologic treatments for coronavirus disease 2019 (COVID-19). JAMA. v.323 p.1824-1836. 2020.

VIJGEN L.; KEYAERTS, E., LEMEY, P. et al. Evolutionary history of the closely related group 2 coronaviruses: Porcine hemagglutinating encephalomyelitis virus, bovine coronavirus, and human coronavirus OC43. J Virol. v.80, p.7270-7274. 2006. 
Marcos Silveira Buckeridge

ఐmsbuck@usp.br

ORCiD: https://orcid.org/0000-0002-5455-8136
Submitted on: 29/05/2020

Accepted on: 30/05/2020

2020;23:e0121

How to cite: BUCKERIDGE, M. S. Global analysis of the infection by COVID-19. Ambiente $\&$ Sociedade. São Paulo, v. 23, p. 1-8, 2020. 


\title{
Análise Global da infecção por COVID-19
}

\author{
Marcos Silveira Buckeridge
}

São Paulo. Vol. 23, 2020

Ideias em debate

A época $\mathrm{CO}$. VID-19: Pesquisa interdisciplinar e uma nova ética sustentável e justa
Resumo: A evolução global da pandemia da COVID-19 gerou um dos eventos históricos mais importantes do século XXI, com consequências imprevisíveis sobre a economia, o ambiente e a saúde mundial. Neste trabalho eu compilei dados disponíveis em bancos de dados públicos e examinei os níveis de infecção de 56 países com mais de 5 mil casos confirmados e calculei as percentagens de infecções por 100 mil habitantes. O padrão encontrado revelou marcante diferença entre países asiáticos e europeus, com níveis de infecção bem maior nesses últimos. Países da América Latina e do Oriente Médio foram intermediários. Três fatores podem ter gerado os padrões observados: estratégias de distanciamento social, fatores genéticos e o nível de testagem. Concluo que a evolução da pandemia poderia ser mais bem explicada como um fenômeno multifatorial e vista melhor de um ponto de vista sistêmico.

Palavras-chave: COVID-19, infecção, análise global, distanciamento social, testagem.

Como citar: BUCKERIDGE, M. S. Análise Global da infecção por COVID-19. Ambiente \& Sociedade. São Paulo, v. 23, p. 1-8, 2020.

DOI: http://dx.doi.org/10.1590/1809-4422asoc20200121vu2020L3ID 


\title{
Análisis global de la infección por COVID-19
}

\author{
Marcos Silveira Buckeridge
}

São Paulo. Vol. 23, 2020

Ideas en debate

La época $\mathrm{CO}$. VID-19: investigación interdisciplinaria y una nueva ética sostenible y justa
Resumen: La evolución global de la pandemia de COVID-19 ha generado uno de los eventos históricos más importantes del siglo XXI, con consecuencias impredecibles para la economía, el medio ambiente y la salud global. En este trabajo, compilé datos disponibles en bases de datos públicas y examiné los niveles de infección de 56 países con más de 5,000 casos confirmados y calculé los porcentajes de infección por 100,000 habitantes. El patrón encontrado reveló una marcada diferencia entre los países asiáticos y europeos, con niveles mucho más altos de infección en este último. Los países de América Latina y Medio Oriente fueron intermediarios. Tres factores pueden haber generado los patrones observados: estrategias de distancia social, factores genéticos y el nivel de prueba. Concluyo que la evolución de la pandemia podría explicarse mejor como un fenómeno multifactorial y verse mejor desde un punto de vista sistémico.

Palabras clave: COVID-19, infección, análisis global, distancia social, prueba.

Como citar: BUCKERIDGE, M. S. Análisis global de la infección por COVID-19. Ambiente \& Sociedade. São Paulo, v. 23, p. 1-8, 2020.

DOI: http://dx.doi.org/10.1590/1809-4422asoc20200121vu2020L3ID 